\title{
Sharing economy and public governance
}

\section{Adilson Giovanini 1}

1 Universidade do Estado de Santa Catarina / Department of Public Governance, Balneário Camboriú / SC - Brazil

\begin{abstract}
The term sharing economy is used in specialized literature to identify how the Internet, smartphones, and applications are changing the global economic dynamic. This article presents documentary research focused on private sharing applications that have emerged in recent decades, intending to contribute to the improvement of local public management. Descriptive data analysis and regression were used to characterize the local governments' adherence to new technologies and to identify how these new technologies affect the fiscal performance of municipalities measured by the FIRJAN Fiscal Management Index. The results obtained show that shared economy Apps can contribute in different ways, with emphasis on greater cooperation and coordination within and between local governments, reduction in the underutilization of assets, greater access and improvement in the quality of public services, and greater interaction and citizen participation in public decisions. The estimated regression shows that the use of new communication technologies contributes to improving the municipalities' fiscal performance. However, these technologies are little used and should be encouraged in local public administrations.
\end{abstract}

Keywords: shared economy; counties; local public management.

\section{Economia compartilhada e governança pública}

O termo economia compartilhada é empregado na literatura especializada para identificar a forma como a internet, os smartphones e os aplicativos estão modificando a dinâmica econômica mundial. Este artigo apresenta uma pesquisa documental realizada para identificar os aplicativos de compartilhamento que surgiram nas últimas décadas e o modo como estão contribuindo para a melhoria da gestão pública local. Utilizou-se a análise descritiva dos dados e uma regressão para caracterizar a adesão às novas tecnologias pelos governos locais e para identificar o modo como afetam o desempenho fiscal dos municípios, mensurado a partir do Índice FIRJAN de Gestão Fiscal (IFGF). Os resultados obtidos mostram que os aplicativos de economia compartilhada podem contribuir de diferentes formas, com destaque para: a maior cooperação e coordenação intra e entre governos locais, redução na subutilização de ativos, maior acesso e melhoria na qualidade dos serviços públicos, e maior interação e participação dos cidadãos nas decisões públicas. A regressão estimada mostra que o emprego das novas tecnologias de comunicação contribui para a melhoria no desempenho fiscal dos municípios. Contudo, essas tecnologias são pouco utilizadas, sendo necessárias iniciativas que estimulem a utilização de aplicativos de compartilhamento nas gestões públicas locais. Palavras-chave: economia compartilhada; municípios; gestão pública local.

\section{Economía compartida y gobernanza pública}

El término economía compartida se utiliza en la literatura especializada para identificar cómo la Internet, los smartphones y las aplicaciones están cambiando la dinámica económica mundial. Este artículo presenta una investigación documental realizada para identificar las aplicaciones de compartición que surgieron en las últimas décadas y cómo están contribuyendo a la mejora de la gestión pública local. Se utilizó el análisis descriptivo de datos y la regresión para caracterizar la adhesión a las nuevas tecnologías por parte de los gobiernos locales y para identificar cómo afectan el desempeño fiscal de los municipios, medido a partir del Índice FIRJAN de Gestión Fiscal (IFGF). Los resultados obtenidos muestran que las aplicaciones de economía compartida pueden contribuir de diferentes formas, con énfasis en: mayor cooperación y coordinación dentro y entre los gobiernos locales, reducción de la subutilización de activos, mayor acceso y mejora en la calidad de los servicios públicos y mayor interacción y participación ciudadana en las decisiones públicas. La regresión estimada muestra que el uso de nuevas tecnologías de la comunicación contribuye a mejorar el desempeño fiscal de los municipios. Sin embargo, estas tecnologías rara vez se utilizan y se necesitan iniciativas para fomentar el uso de aplicaciones de compartición en las gestiones públicas locales.

Palabras clave: economía compartida; municipios; gestión pública local. 


\section{INTRODUCTION}

The term Sharing economy or sharing economy had emerged in the United States in the 1930s, in the context of the Great Depression, and is directly related to the emergence of social technologies and the search for alternatives in the face of population growth and the depletion of existing resources as well.

In the academic world, its introduction goes back to Lessig (2008), by arguing that there are two economies: commercial and shared. In the first, the commercial economy, is permeated by the logic of the market, in which products and services have tangible monetary value, be it money or work. The Sharing economy, on the other hand, identifies transactions that do not involve monetary exchange, being regulated by a set of social relations (friendships and rules of social interaction) and not only by price metrics.

The terms mesh economy (Gansky, 2010), collaborative consumption (Botsman \& Rogers, 2009), connected consumption (Dubois, Schor, \& Carfagna, 2014) and elancing (Aguinis \& Lawal, 2013) also emphasize sharing as a central element of transactions. Thence definitions that are close (if not equivalent) to the concept of Sharing economy can be considered, which gained greater prominence due to its more appealing name (Sundararajan, 2016).

The Sharing economy is often misinterpreted as synonymous with related concepts which identify specific aspects related to the change in the nature of economic transactions, brought about by the use of new digital technologies. The distinction between these concepts is necessary, as follows:

1) Platform economy (digital platform or online platform economy): it shows to be broader and encompasses all commercial and non-commercial online transactions.

2) On-demand economy: refers to the digital supply of activities that seek to meet consumer demand through immediate and flexible access to goods and services (for example: makeup, meal delivery, manual repairs).

3) Gig economy: groups the most flexible and temporary forms of work that have emerged in response to the advance in online transactions (Mulcahy, 2016).

4) Peer-to-peer economy: emphasizes the growing decentralized and punctual

character presented by online transactions (Aslam \& Shah, 2017).

The Sharing economy is directly related to the crowd movement and the concept of crowd economy, a term coined by Reinaldo Pamponet, in 2011, to identify the development of a new economy, endowed with new exchange values which emerge from collective movements strongly permeated by interaction between people.

The concept of crowd economy adds to the microeconomic theories of labor value and marginal utility, offering a response to the tragedy of common goods, for which common goods tend to be overused. According to Benkler (2002, 2006), network technology manages to avoid excessive consumption of these goods through the so-called production of common goods by peers in a network.

Unlike traditional forms of ownership, in which goods are exclusive (if it is mine, it is not yours), in networked peer production they are inclusive (it belongs to all of us). Thus, anyone can have access to the goods, as long as they respect the established rules (Bauwens, 2005).

The definition of the correct access rules represents a key element, responsible for promoting the efficient use of these goods. The emergence and success of new digital technologies enable the 
development of more sophisticated rules, a fact that supports the explanation of the rapid advance of the Sharing economy since the 1990s.

As a matter of fact, should be noted that there is no consensus in the literature that the term Sharing economy is the most appropriate. Kaplan (2014) and Hamari, Sjöklint, and Ukkonen (2016), for example, argue that this term is used inappropriately to describe human activities characterized by the emergence of new forms of work organization and the sharing of surplus productive capacity in exchange for money. The result is the emergence of an economy characterized by peer-to-peer (p2p) transactions, which are more horizontal and decentralized.

According to Bradshaw and Brook (2014) and Eckhardt and Bardhi (2015), activities related to the Sharing economy are actually based on providing access to underutilized assets, being intermediated by the market from digital platforms and specialized companies. Thus, the term economics of access is more appropriate.

Regarding public governance, the literature has shown that the Sharing economy can contribute to improving the management of local governments (Clarke, Lindquist, \& Roy, 2017; Ganapati \& Reddick, 2018; Hong \& Lee, 2018; Hong \& Ryu, 2019; Selloni, 2017; Tomkinson, 2017).

There is a growing international literature that analyzes the effects of sharing on the public sector. Notwithstanding, regarding to this subject, no study has been found in the national literature.

Thus, the foremost purpose of this article is to introduce the literature on the sharing of public assets in the national territory, seeking to make public managers aware of the different ways in which the Sharing economy can contribute to the improvement of the services offered.

Major interests in this article focus on the documentary research (Marconi \& Lakatos, 2002) by surveying the private sharing applications that have emerged in the last decade at national and international levels. The data presented is obtained by conducting a search on articles and technical reports, with the pertinent information collected in newspapers, websites and reference pages on the Internet. The applications are classified into different categories, according to the characteristics displayed.

Furthermore, a regression by ordinary least squares (OLS) is estimated to identify whether the digitalization of municipal services influences the fiscal performance of Brazilian municipalities, measured through the FIRJAN Tax Management Index (IFGF).

The advantage presented by the regression is that it allows to calculate the impact generated by the digitalization of public services on the fiscal performance of the municipalities. This fact justifies the use of this methodological tool to identify the effect of new digital technologies on the fiscal management of Brazilian municipalities.

Data used were extracted from the online database provided by the Brazilian Institute of Geography and Statistics (IBGE) for the year 2014, for 5,465 municipalities, the year in which the IBGE collected data on the provision of public services through the Basic Municipal Information Survey (MUNIC).

In addition to this Introduction, the article is structured in five more sections. Initially, at section 2, Sharing economy, presents the main studies on this form of economy. Subsequently, at section 3, Public Governance and Sharing, shows how the Sharing economy is contributing to the improvement of local public management. Thereafter, at section 4, places the Results Found for the Descriptive Statistics and for the Estimated Regression, brings the results obtained for the estimated regression and lastly, at section 5, the Final Considerations of this work are exposed. 


\section{SHARING ECONOMY}

The acceleration in the expansion of the Sharing economy, driven by technological advances, happens since the 1990s in the United States. The development of information technologies, especially the internet, has led to the emergence of a new consumption pattern based on access to goods and services, which makes the acquisition of goods unnecessary (Schor, 2016).

Roughly speaking, the Sharing economy is characterized by two key dimensions. First, it depends centrally on the internet to carry out transactions. Second, asset sharing creates value, i.e., assets are rented rather than shared, thence transactions are commercial rather than free (Kaplan, 2014; Sundararajan, 2016).

In the understanding of Gansky (2010), the Sharing economy represents a new trend in a strong expansion process, mainly in developed countries, in which it emerges in the form of new organizations and new business models, with a focus on the sharing of human and physical resources, including the creation, production, distribution, trade and shared consumption of goods and services by people and organizations. This view on Sharing economy is defined by Dubois et al. (2014) as a set of connected consumption initiatives that promotes product reuse, eliminates intermediaries and creates pointto-point interaction mechanisms (P2P).

Its expansion is reinforced by the diffusion of communication technologies, mainly smartphones and the application market (Ganapati \& Reddick, 2018). With the increased use of mobile devices and the spread of wireless broadband, smartphones and sensors connected to the internet, the economy of mobile applications and location-based services emerges. Smartphones enable new opportunities for the P2P network and location and monitoring sensors capture users' location information in real time, which information is used to provide personalized services (Ganapati, 2015).

Sharing economy companies use the internet to provide the platforms and generate the information that makes it possible to establish connections between people and companies over time and space. In turn, the platforms provide the necessary technological infrastructure to promote sharing, interactions, communication and network participation. The Sharing economy is multifaceted, bringing together different groups of producers and consumers with the aim of grouping users and promoting the sharing of goods and the transformations brought about by this new trend are of such magnitude that Rifkin (2016) argues that it represents the emergence of a new model of post-capitalist production. In fact, the Sharing economy has grown exponentially in the last decade, a process that tends to intensify with the advance in artificial intelligence, industry 4.0 and 3D printers, including, the market value of some of the Sharing economy platforms already exceeds the value established firms in the sector.

The Uber, an American multinational company, providing electronic services in the field of urban private transport, for example, emerged in 2009 and in 2018 was worth US $\$ 68$ billion, higher than that of each of the three largest American car companies: Chrysler, Ford and General Motors (Chen, 2015). Airbnb, which emerged in 2008, in 2018 was valued at $\$ 30$ billion, higher than that of the Hilton hotel chain and almost the value of the Marriott hotel chain (Ganapati \& Reddick, 2018).

In addition to the use of new digital technologies to develop more efficient rules of access to goods and services, as the advancement of the Sharing economy is also reinforced by three modern trends: 1) the growing awareness of the need to adopt more sustainable (Bradshaw \& Brook, 2014);2) the characteristic mentality of generation $Y$, who has greater ease in using new technologies (Bull, 2010; Rifkin, 2016); and 3) the international crisis of 2008, which created a fertile field for the use of new technologies in order to rationalize consumption (Marshall, 2015). 
In addition to the aforementioned, there are still three additional factors that contribute to the success of sharing applications.

1) The elimination of intermediaries: the ease of communication generated by smartphones means that people can trade goods directly from specialized digital platforms (Rifkin, 2016);

2) The reduction in information asymmetry: made possible by the emergence of applications that provide information in real time about users (Weber, 2014);

3) Monitoring and using reputation measurement metrics: they eliminate opportunistic behavior, help to solve the hitchhiker problem (Thierer, Koopman, Hobson, \& Kuiper, 2015; Sundararajan, 2016) and enable the private offer of common goods (Benkler, 2002).

The biggest restrictive factor that existed in the advancement of sharing applications was the presence of opportunistic behavior, which makes it impossible to offer public goods. The solution found by the Sharing economy is the construction of metrics to measure the reputation of users.

The pressure generated by the evaluation and the possibility of not being able to enjoy the benefits provided by sharing applications encourages each user to adopt behaviors that maximize the evaluation received. Thus, the creation of access metrics in the form of mechanisms for measuring reputation makes it possible to offer goods through applications, providing security and making transactions possible (Botsman, 2017; Gandini, 2016).

The value of sharing apps increases when more stringent criteria are put in place that prevent people with opportunistic behavior from using them again. The reputation of the application is given by the reputation of the users, so that its survival and growth depend on the adoption of strict and transparent criteria, which raise the quality of the services offered and encourage service providers to maximize the users' experience (Botsman, 2017).

In chronological terms, the emergence of the Sharing economy can be broken down as shown below. In the mid-1990s, the emergence of the internet stimulated electronic commerce, with the emergence of the first online P2P markets, such as Amazon and eBay. In the 2000s, social media was born: LinkedIn, in 2002; Orkut and Facebook, in 2004; Twitter, in 2006, and WhatsApp, in 2009. These innovations enabled P2P communication within personal and professional collaborative networks (Tapscott \& Williams, 2008).

At the very beginning of the 2000s, the first platforms for sharing media and digital content also emerged, among which the following stand out: Flickr and Vimeo, created in 2004; YouTube, 2005; SlideShare, 2006; Pinterest, 2010; Instagram, 2010; Snapchat, 2011; and Tik Tok, 2016. And the collective content development platforms, such as: Blogger, 1999; Wikipedia, 2001; Topcoder, 2001; Google Docs, 2006; GitHub, 2008, and Waze, 2009.

In 2007, when the iPhone was launched, applications for cell phones began to emerge, a fact that enabled the rapid development of the market for sharing applications and the emergence of applications responsible for providing specialized marketplaces for carrying out specific transactions. As a result, there is a rapid diversification in sharing initiatives, which occurs in the form of a wave of emergence of specialized startups. Table 1 shows the main startups that emerged in the period 2008-2019, broken down according to the industry in which they operate.

Among the economic activities in which the emergence of Sharing economy startups can be seen, platforms that specialize in sharing: 
RAP | Sharing economy and public governance

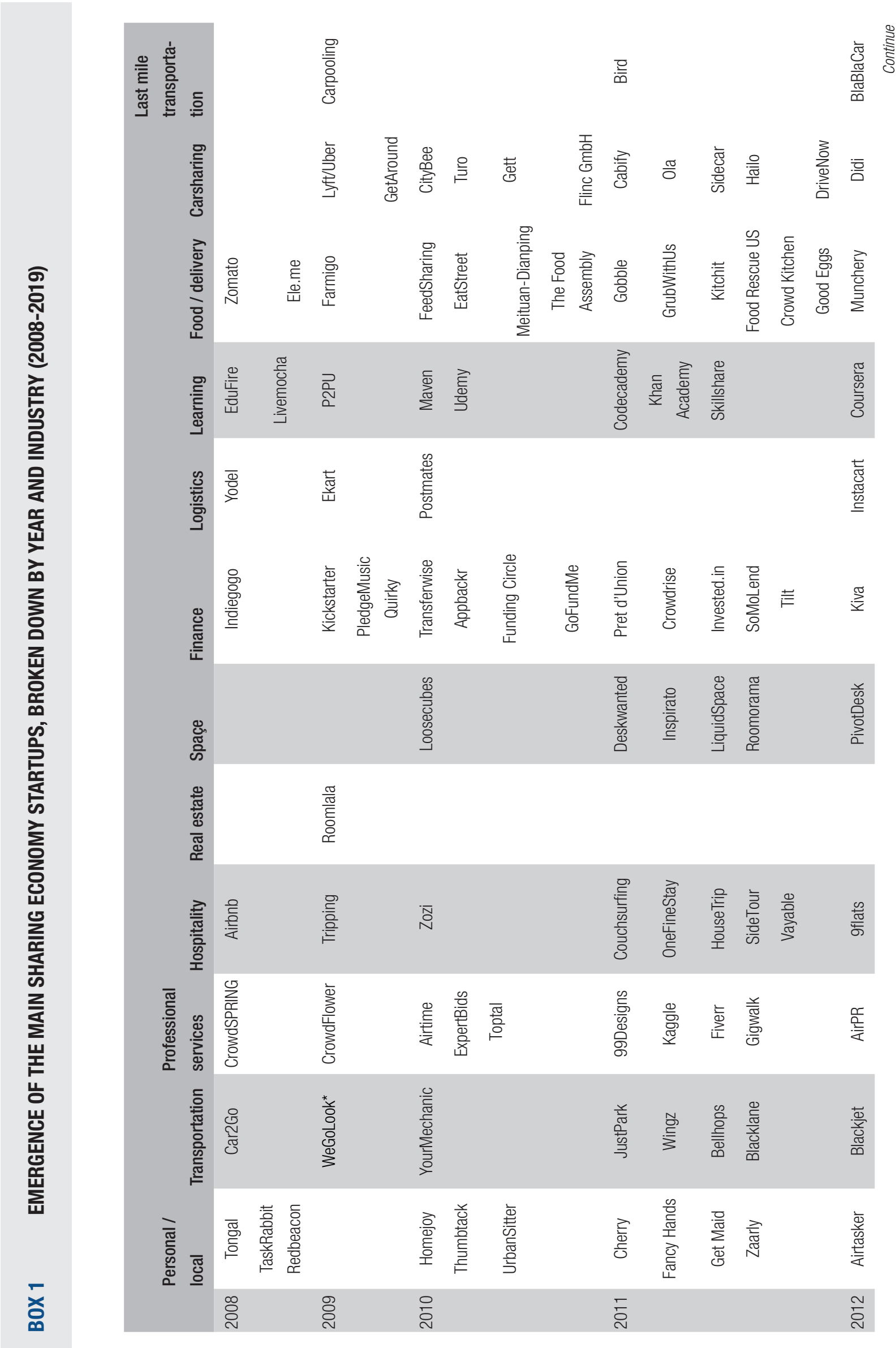

Brazilian JoURnal Of pUblic administration ｜ Rio de Janeiro 54(5):1207-1238, Sept. - Oct. 2020 
RAP | Sharing economy and public governance

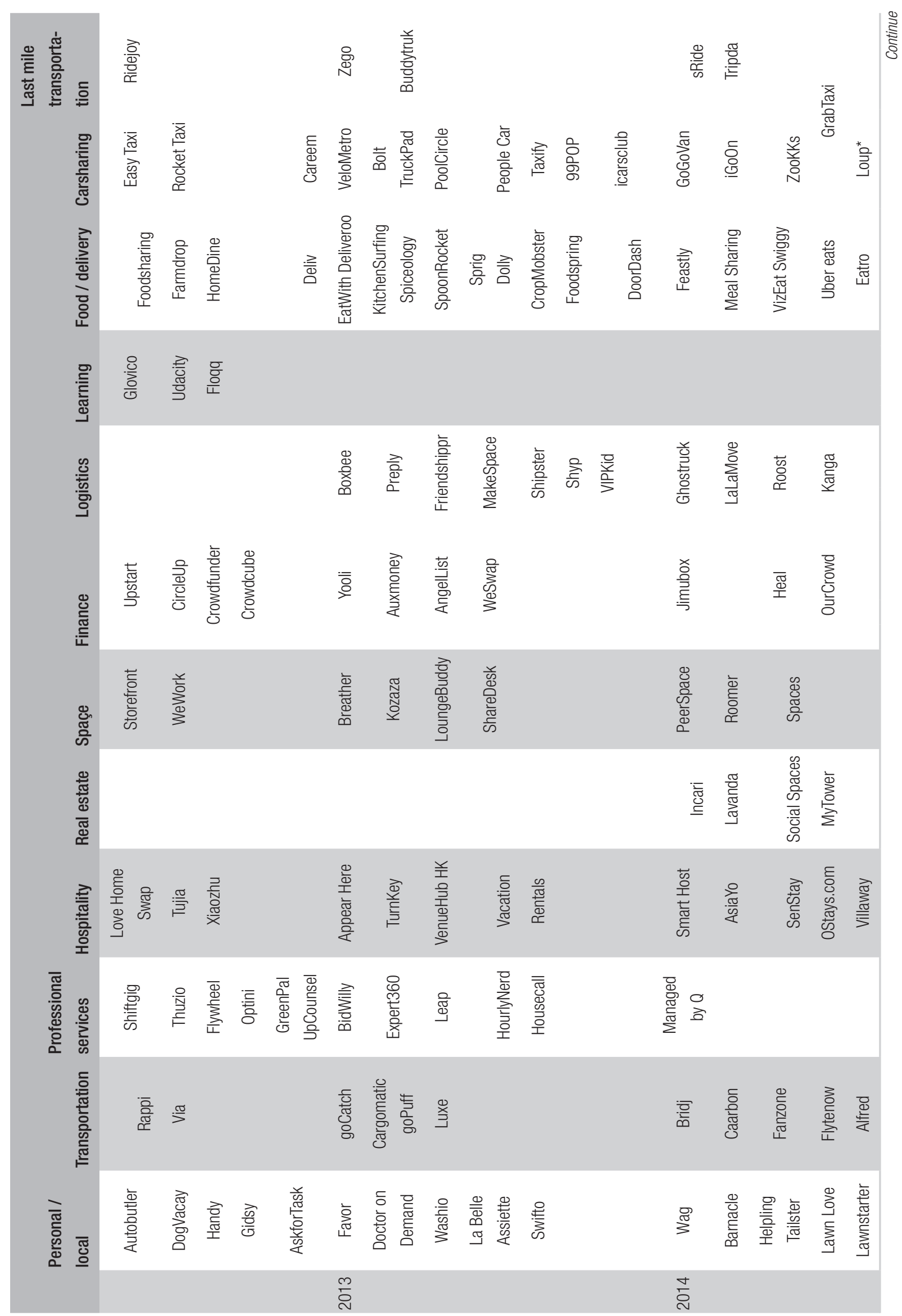


RAP | Sharing economy and public governance

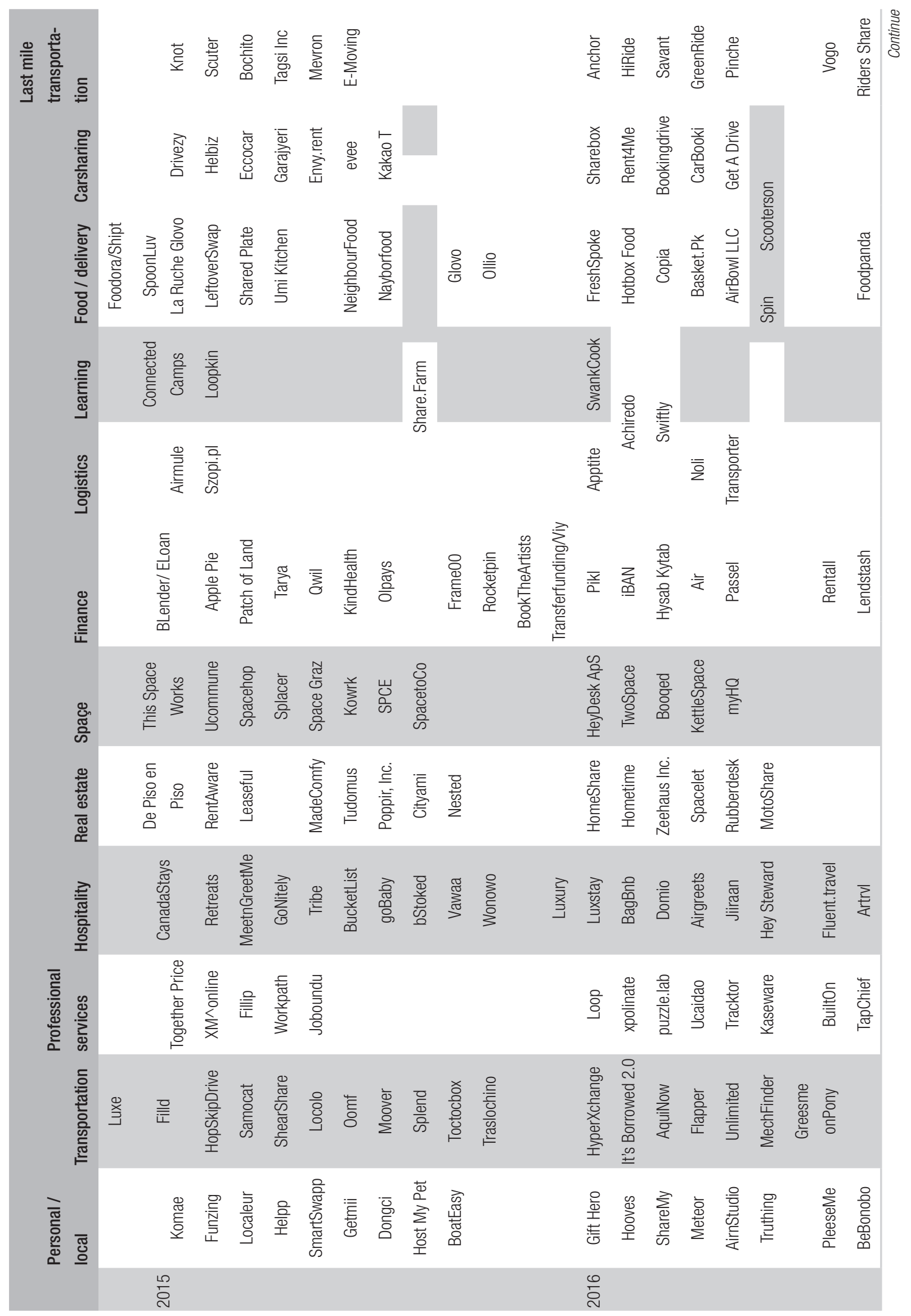

Brazilian JOURnal OF PUblic administration ｜ Rio de Janeiro 54(5):1207-1238, Sept. - Oct. 2020 
RAP | Sharing economy and public governance

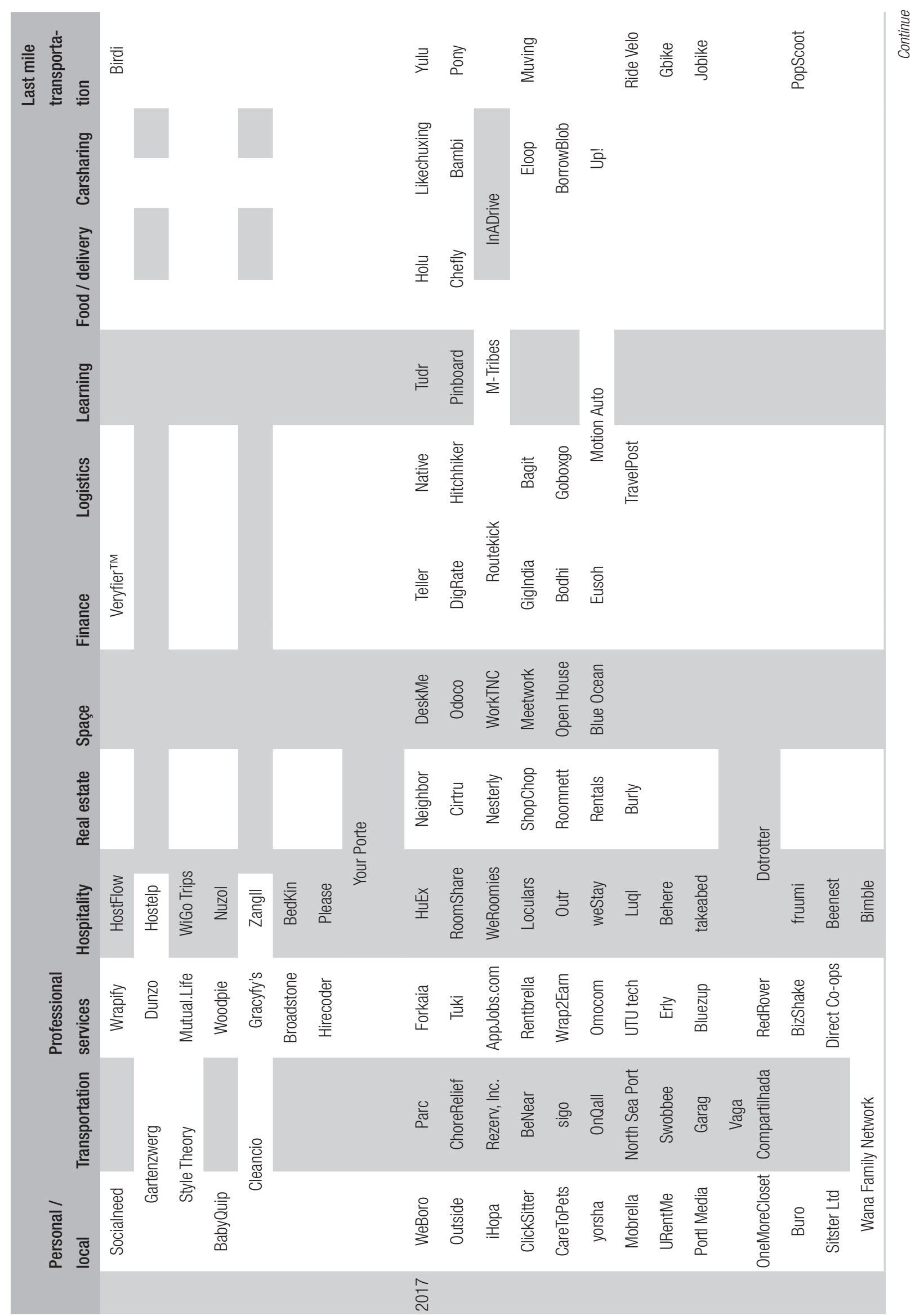


RAP | Sharing economy and public governance

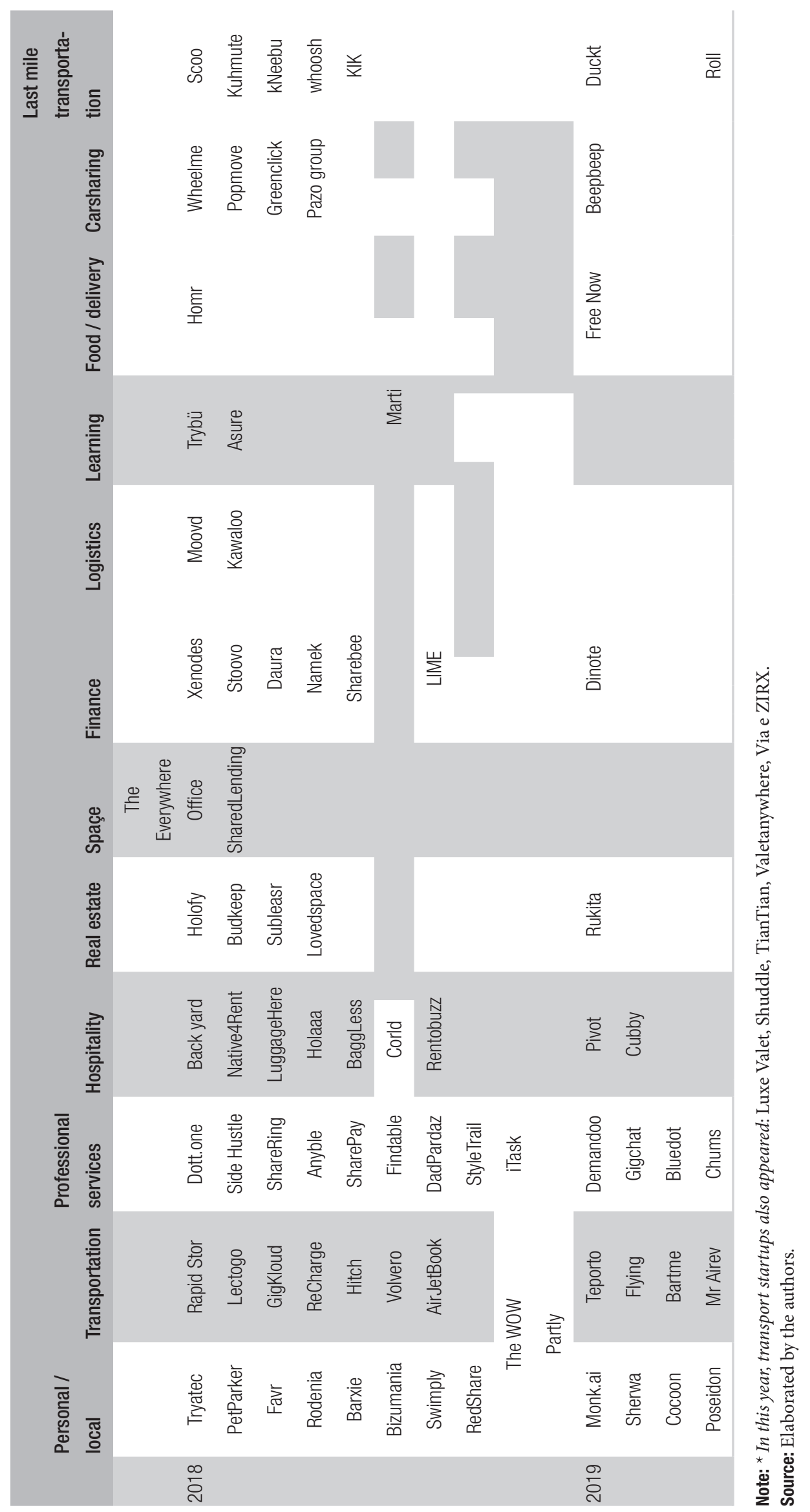

Brazilian Journal of PUblic administration | Rio de Janeiro 54(5):1207-1238, Sept. - Oct. 2020 
Among the economic activities in which the emergence of sharing economy startups is envisaged, platforms that specialize in sharing:

- Personal/local services: Tongal and TaskRabbit, created in 2008; Homejoy, ZOZI, Thumbtack and UrbanSitter, 2010; Cherry, 2011; Airtasker and DogVacay, 2012; Favor and Doctor on Demand, 2013; Lawn Love, 2014; Localeur, 2015; Gift Hero, Hooves, ShareMy, 2016; WeBoro, Outside, iHopa, ClickSitter, 2017; Tryatec, PetParker, Rodenia, Barxie, 2018; Monk.ai, Sherwa, Cocoon, Poseidon, 2019.

- Transport: Car2Go, 2008; JustPark, Wingz, Bellhops, Blacklane, 2011; Blackjet, Rappi, Via, 2012; goCatch, Cargomatic goPuff, Luxe, 2013; Bridj, Caarbon, Fanzone, Flytenow, 2014; Filld, HopSkipDrive, BoatEasy, ShearShare, 2015; Gartenzwerg, Style Theory, 2016; Parc, ChoreRelief, Rezerv, BeNear, Sigo, 2017; Rapid Stor, Lectogo, GigKloud, ReCharge, Hitch, Volvero, AirJetBook, 2018; Teporto, Flying, Bartme, Mr Airev, 2019.

- Professional services: crowdSPRING, 2008; CrowdFlower, 2009; Airtime and ExpertBids, 2010; 99Designs e Kaggle, 2011; AirPR, Shiftgig and Thuzio, 2012; BidWilly and HourlyNerd, 2013. Managed by Q, 2014; Together Price, $X \mathrm{X}^{\wedge} \wedge$ online, Fillip, Workpath, Joboundu, 2015; Loop, Xpolinate, Puzzle.lab, Ucaidao, Tracktor, 2016; Forkaia, Tuki, AppJobs.com, Rentbrella, 2017; Dott. one, Side Hustle, ShareRing, 2018; Demandoo, Chums, Bluedot, Gigchat, 2019.

- Hospitality: Airbnb, 2008; Tripping, 2009; Couchsurfing, OneFineStay, HouseTrip, 2011; 9flats, Love Home Swap, Tujia, Xiaozhu, 2012; Appear Here, TurnKey Vacation Rentals, VenueHub HK, 2013; Smart Host, AsiaYo, SenStay, 2014; CanadaStays, Retreats, MeetnGreetMe, GoNitely, Tribe, 2015; Luxstay, BagBnb, Domio, 2016; HuEx, RoomShare, WeRoomies, Loculars, 2017; Back yard, Native4Rent, LuggageHere, 2018; Pivot, Cubby, 2019.

- Real estate services: Roomlala, 2009; Incari, Lavanda, Social Spaces, MyTower, 2014; De Piso en Piso, RentAware, MadeComfy, 2015; HomeShare, Hometime, Spacelet, Rubberdesk, MotoShare, 2016; Neighbor, Cirtru, Nesterly, 2017; Holofy, Budkeep, Subleasr, Lovedspace, 2018; Rukita, 2019.

- Espace: Loosecubes, 2010; Deskwanted, Inspirato, LiquidSpace, Roomorama, 2011; PivotDesk, Storefront, WeWork, 2012; Breather, Kozaza, LoungeBuddy, ShareDesk, 2013; PeerSpace, Roomer, Spaces, 2014; This Space Works, Ucommune, Spacehop, Splacer, 2015; HeyDesk ApS, TwoSpace, myHQ, 2016; DeskMe, Odoco, WorkTNC, Meetwork, Open House, Blue Ocean, 2017; The Everywhere Office, 2018.

- Finances: Lending Club, 2006; Transferwise, 2010; Pret d'Union, 2011; Kiva, Upstart, em 2012; Yooli and Auxmoney, 2013; Jimubox, 2014; Blender, ELoan, Apple Pie, Patch of Land, Pret d'Union, Tarya and Transferfunding, 2015; Pikl, Lendstash, Veryfier ${ }^{\text {Tw }}$, Hysab Kytab, 2016; Teller, Eusoh, DigRate, 2017; Xenodes, Stoovo, Daura, 2018; Dinote, Variable Labs, 2019.

- Logistic: Postmates, 2010; Bellhops and Instacart, 2012; Boxbee, Deliv, Friendshippr, MakeSpace, Shipster and Shyp, 2013; Ghostruck, LaLaMove and Roost, 2014; Airmule, Szopi.pl, 2015; Apptite, Achiredo Technologies, Swiftly, Noli, Transporter, 2016; Native, Hitchhiker, Routekick, 2017; Moovd, kawaloo, 2018.

- Learning: EduFire, Livemocha, 2008; P2PU, 2009; Maven and Udemy, 2010; Codecademy, Khan Academy and Skillshare, 2011; Coursera, Glovico and Udacity, 2012; Connected Camps, Loopkin, 2015.

- Food/delivery: Zomato, Ele.me, 2008; FeedSharing, EatStreet, Meituan-Dianping, 2010; Gobble, GrubWithUs and Kitchit, 2011; Munchery, 2012; EatWith, KitchenSurfing, SpoonRocket and Sprig, 2013; Feastly, Meal Sharing and VizEat, 2014; La Ruche, 2015; FreshSpoke, Hotbox Food, 2016; Basket.Pk, AirBowl LLC, SwankCook, 2017; Holu, Chefly, 2019; Homr, 2019. 
- Carsharing: Lyft, Uber, GetAround, 2008; CityBee, Turo, Gett, Flinc GmbH, 2009; Cabify, Ola, Sidecar, 2010; Didi, Easy Taxi, Rocket Taxi, 2011; VeloMetro, Bolt, Taxify, 99POP, 2013; GoGoVan, iGoOn, ZooKKs, GrabTaxi, Loup, 2014; Drivezy, Eccocar, 2015; Sharebox, Rent4Me, 2016; Likechuxing, Bambi, M-Tribes2017; Wheelme, Popmove, Greenclick, Pazo group, 2018; Beepbeep, Free Now, 2019.

- Last mile transportation/Carpool: Carpooling, 2009; Bird, 2011; BlaBlaCar, Ridejoy, Deliv, 2012; Zego, 2013; sRide, Tripda, 2014; Knot, Scuter, Bochito, Tagsi, Mevron, E-Moving, 2015; Anchor, HiRide, Savant, GreenRide, 2016; Yulu, Pony, InADrive, 2017; Scoo, Kuhmute, kNeebu, 2018; Duckt, Roll, 2019.

The rapid emergence and dissemination of sharing platforms shows that the transformations generated by the Sharing economy are transversal to the traditional economy. They cover different activities, culminating in huge contributions that have an increasing impact on economic dynamics.

\section{PUBLIC GOVERNANCE AND SHARING}

Similar to the private sector, the Sharing economy also registers the emergence of startups with solutions that promise to contribute to an increase in the efficiency and quality of public goods and services. This section reviews these initiatives, identifying challenges and opportunities related to the public sector.

To understand the effect of the Sharing economy on the public sector, it is necessary to resume some studies enshrined in the literature on economics and public governance. As highlighted by Lloyd (1833) and rescued by Hardin (1968), free access to common goods tends to lead to overexploitation, since the benefits arising from these goods are individual whereas the costs are distributed among everyone who uses them. To the extent that common goods need to be privatized and / or regulated for their exploitation to take place efficiently. Subsequently, Ostrom, Burger, Field, Norgaard, and Policansky (1999) show that agents develop solutions to the problem of common goods. The definition of access rules makes it possible to use them collectively. Furthermore, Axelrod (1984) argues that, in seeking to maximize private gains, agents are encouraged to cooperate, as collective self-control and cooperation prove to be advantageous for individuals.

More recently, Benkler (2002) argues that new models of production of common goods, called "production of common goods by peers in a network", are emerging. In these systems, assets are organized in a decentralized, collaborative and non-proprietary manner, without the need for government intervention. Modularization and wide availability of information make it possible for agents to identify the best tasks. On the other hand, the development of mechanisms for monitoring activities, such as peer review and quantitative control of collaborations, are sufficient for transactions to be carried out efficiently. Furthermore, Surowiecki (2007) shows that three conditions are necessary for a group of people to be able to act collectively, making efficient decisions without the need for supervision/intermediation by an external agent: diversity of opinions, independence and decentralization.

The Sharing economy, through the intensive use of the internet and the development of new monitoring systems, manages to identify and classify users in a reputation system and thus presents 
self-regulatory mechanisms with properties similar to those observed for the production of common goods by peers networking (Botsman, 2017; Sundararajan, 2015). These systems are used to mitigate the hitchhiker problem and to complement local governments in the provision of typically public service goods (Weber, 2014).

The advancement of the Sharing economy creates important debates about the role, in terms of regulation to be performed by the local governments. This phenomenon can be illustrated by the advancement of companies like Uber, which, by encouraging highly decentralized P2P transactions, obliges governments to revise their traditional regulatory instruments (Conselho Administrativo de Defesa Econômica [CADE], 2018; Esteves, 2015; Lei no 13.640, 2018; Mendes \& Ceroy, 2015; Nota Técnica no 39/2018, 2018; Resende \& Lima, 2018; Resolução no 148, 2019; Terrien, Maniak, Chen, \& Shaheen, 2016), giving greater freedom for companies to develop their own governance mechanisms (Bond, 2015; Cohen \& Sundararajan, 2015; Rauch \& Schleicher, 2015).

Although the literature on shared economics is quite optimistic and argues that self-regulation will reduce the need for local governments (Cannon \& Summers, 2014; Cramer \& Krueger, 2016; Koopman, Mitchell, \& Thierer, 2015; Möhlmann \& Geissinger, 2018; Puschmann \& Alt, 2016; Schor, 2016; Sundararajan, 2017), some authors are reticent. Stemler (2017a, 2017b) and Harris (2017), for example, identify flaws in sharing applications and show that reputation and evaluation systems remain subject to manipulation and the presence of cognitive biases. Zrenner (2015), Smith and Leberstein (2015), Codagnone, Abadie, and Biagi (2016), Erickson and Sørensen (2016) and Harris (2017) show that the Sharing economy creates new challenges, such as the growing precariousness in labor relations and the need to protect consumers and property rights.

Dellarocas (2010) and Brescia (2016) argue that this dual character of the Sharing economy, characterized by the simultaneous presence of benefits and new challenges, demands the development of more flexible and intelligent government regulation mechanisms. Public managers need to remain open and innovative, adopting regulations that promote the improvement of reputation systems, experimentation and institutional innovation. However, they must also identify the specific needs for intervention and regulation, reconciling the adoption of measures that facilitate the advancement of the Sharing economy with those that seek to correct the resulting failures and anomalies.

The specialized literature also shows that the solutions proposed by the Sharing economy companies may contribute to the advancement of municipal public management instruments (Clarke et al., 2017; Hong \& Lee, 2018; Hong \& Ryu, 2019; Selloni, 2017; Tomkinson, 2017; Zon, 2015). According to Moon et al. (2014), the advent of the internet in the mid-1990s expanded the scope of digital government to electronic government, with a focus on services external to citizens. From the mid-2000s, with the emergence of new sharing applications, the government came to be seen as a platform for interactive co-production with citizens, using information technologies to solve public problems (Albinsson \& Perera, 2012; Heinrichs, 2013; Kirchherr, Reike, \& Hekkert, 2017; Linders, 2012; Zeemering \& Delabbio, 2013).

Currently, they have many possibilities for creating sharing platforms for specific purposes, depending on the need and specificities of public services offered to citizens. According to Chasin and Scholta (2015) and Turban, Outland, King, Lee, Liang, and Turban (2018), these platforms can be classified according to the way they promote the interaction between public and private entities. Among the different possible forms of interaction, the most relevant are the sharing of government with government (government to government - G2G), government with citizens (government to 
citizens - G2C), government with companies (government to business - G2B) and among citizens themselves (citizens to citizens - C2C).

Among the sharing initiatives available to the public sector, we highlight: 1) the use of third-party car sharing platforms, which can drastically reduce the size of the fleets of local governments; and 2) the use of services such as Lyft, Zipcar and Uber in order to reduce the cost of managing its own fleet, cutting capital and operating expenses (Accenture, 2016).

For example, in the San Francisco Bay area, local government officials are using Lyft to provide public transport, reduce costs and facilitate the travel of public officials as well. Similarly, the city of Chicago uses Zipcar to meet some of the needs of its fleet, resulting in savings of $\$ 0.25$ per mile in terms of owning and operating its own fleet (Accenture, 2016).

Another possibility is the rental of vehicles between agencies and / or municipalities - G2G. In the last decade, several specialized platforms for sharing public goods and services have emerged, among which ShareOhio.gov and MuniRent stand out. The purpose of these applications is to spread the sharing of equipment and tools among local governments (Accenture, 2016; Clark et al., 2017; Wosskow, 2014). In this context, there are also specialized applications for sharing G2B medical equipment, such as the digital platforms Cohealo and Kaiser Permanente.

G2G sharing of workplaces, using applications like LiquidSpace, and renting private spaces through Airbnb, results in more efficient use of offices and reduces the number of properties needed. Cloudbased tools, mobile applications and wireless access in offices allow employees to work anywhere, reducing costs with physical spaces (Accenture, 2016; Coleman, 2013; Ganapati \& Reddick, 2018).

The use of the internet of things and blockchains and the integration and opening of government databases can also promote the development of applications responsible for promoting direct interaction between government and citizens - G2C (Cherry \& Pidgeon, 2018; Janssen, Konopnicki, Snowdon, \& Ojo, 2017).

Among the countless advantages generated by these forms of sharing, the following stand out: 1) the highest quality, transparency and efficiency in the provision of public services; 2) simplification of legal processes and drafting contracts; 3 ) security; 4) the greater participation of the population in the drafting and approval of laws; 5) the reduction in pollution and traffic jams; 6) greater tracking of disease outbreaks; 7) energy efficiency gains; 8) the tracking of financial transactions; and 9) the development of new information-intensive services (Allessie, Sobolewski, \& Vaccari, 2019; Carter, 2018; Hou, 2017; Jun, 2018; Lyons, Courcelas, \& Timsit, 2018; Ojo \& Adebayo, 2017; Ølnes, Ubacht, \& Janssen, 2017; Rivera, Robledo, Larios, \& Ávalos, 2017).

Among the blockchain applications used by local governments we can highlight:

- Propy, for the issuance of securities and instant contracts;

- Burstiq, Essentia Framework and MedRec, for sharing medical information;

- Voatz and Follow My Vote, for safer and more flexible electoral processes;

- Waltonchain, monitoring the emission of waste;

- Crypto Valley, identity registration;

- Essentia, border control;

- Hyperledger Fabric, tracking carbon credits; 
- Blockchain Food Safety Alliance, food security;

- Gov2Go and VoiceMap HK, access to public services; and

- Louis Dreyfus Co., management of agricultural commodities.

Another field related to local public management that has seen high growth is the sharing between citizens (consumers to consumers or citizens to citizens - C2C) of typically public goods, by reducing or redefining the role played by local governments. This phenomenon is facilitated by greater access to the internet, increasing ease of information sharing, development of sensors and digital monitoring mechanisms and the self-regulation capacity of digital platforms (Sundararajan, 2016).

In this sense, among the existing initiatives are the wi-fi sharing applications (Open Garden and Fon); data (OpenDataSoft); loans for the production of solar energy (Mosaic); and local energy sharing (Gridmates, Trec and Vandebron). These applications, using the "wisdom of the crowds" (Surowiecki, 2006; Tapscott \& Williams, 2008) to decentralize decision-making, contribute to greater efficiency in local governments.

There is also an incipient movement in the use of applications to generate an increasing mass of data that may be used by the government to monitor public services, reducing the need for the generation, storage and management of own data. (Accenture, 2016). Data provided by citizens from platforms such as SeeClickFix and NextDoor can help guide public service delivery and long-term planning. They also enable greater involvement of the population in public decisions (Accenture, 2016).

Although the government cannot rely entirely on information provided by sharing applications, the use of data generated from these platforms can have a positive and significant impact on the way services are designed and delivered. In addition to reducing infrastructure costs, exploring the possibilities created by digital ecosystems allows for greater involvement of citizens in public decisions, making information and decisions more and more decentralized. Mobile devices create the possibility for citizens to become co-creators of services and public policies (Accenture, 2016).

In addition to the aforementioned applications, there are several others that seek to promote social integration, facilitating citizens' access to managers and information generated by the public sector. DriveBC, for example, is used by the government of British Columbia, Canada, to facilitate route planning, by providing information about roads in real time. CitySourced and Snapp, Send Solve are reporting tools to help people report civic issues, including public safety and environmental issues.

In Ireland, the Noise App is used for reports of excessively loud noise. FixMyStreet and Street Bump, either allow people to report problems encountered on the streets. OpenPlans is a planning and transportation tool. Outbarriers provide autonomy for the visually impaired. Electore.Me is used to debate political and social issues. NationBuilder brings together a group of open source tools for communities, including maps, surveys and updates that facilitate interaction between agencies and individuals. OpenPublic enables direct interaction with the public. Open311 is a reporting and tracking system for civic issues.

Applications with different tools, such as the Oxford City Council, Kony as well as the Bradford Metropolitan District Council, assist their users in several tasks, from reporting graffiti to registering readers. Applications such as Open City, on the other hand, bring together volunteers to develop applications according to requests received from local governments. 
In this regard, an area that proposes high growth potential is the opening of public databases for private developers to create applications that expand the functionality and the ways in which the data is used. The development of public-private partnerships specialized in the management of databases and the provision of information can contribute to the greater application of public data and to the development of innovative solutions and services. Among the pioneering initiatives identified, the following stand out: New York City, which opened data on its subway system, and the City-State of Singapore, which opened data on its taxi system.

Indeed, sharing applications encompass a multitude of initiatives that bring the population closer to those in government. Citizens and companies start to participate actively in the identification and development of solutions to public problems and in the co-production of government services (Chasin \& Scholta, 2015). The development of government-to-government (G2G) sharing applications can also bring together the different entities that make up each local government, reducing the underutilization of assets and the overlapping of functions and attributions.

As prominently proposed by Janssen and Joha (2006) and Meilă (2018), service sharing represents a major challenge in terms of public governance. Different entities within the same government have specific internal structures and rules, with different resources, objectives and capacities. The use of shared services requires a governance structure that is capable of solving different needs and requirements of the public organizations involved, being one of the barriers that restrict the progress of the Sharing economy.

Resource sharing results in new problems regarding the way services can be shared and coordinated between different public bodies. Therefore, it requires monitoring by professionals with specialized knowledge and the skills necessary to develop solutions to the problems of coordination that emerge (Accenture, 2016; Meilă, 2018).

Numerous public managers argue that they are not prepared and do not have the necessary resources to apply the principles of Sharing economy. In response to these managers, Accenture (2016) recommends the adoption of the following schedule to mitigate the obstacles that emerge:

1) Use platforms such as Uber and Lyft, for first and last mile transportation; Airbnb to obtain emergency shelters after natural disasters; and MuniRent to share heavy equipment;

2) Eventually, when the need to buy assets arises, first ask yourself whether it is possible to borrow or rent, as the possibilities for sharing are almost unlimited;

3) Make the assets you already have available, identify underutilized resources and use sharing to obtain an additional source of revenue; and

4) Use apps like NextDoor and SeeClickFix to connect with citizens.

\section{RESULTS FOUND FOR DESCRIPTIVE STATISTICS AND ESTIMATED REGRESSION}

Considering that the Sharing economy is an emerging trend, there are no data that allow a more detailed analysis of its contribution to the advancement of management practices adopted by Brazilian municipalities. In view of this limitation, this section conducts a survey of national startups related to the Sharing economy, focused on local governance, analyzes whether Brazilian municipalities provide services over the internet and estimates a regression by MQO to identify the effect of the computerization of public services on the fiscal performance of municipalities. 


\subsection{The Sharing economy in Brazilian municipalities}

The Sharing economy startups focused on public governance, identified from the survey conducted, are consolidated below, being broken down according to the nature of the services provided.

- Providing information to residents: Prefeitura de Araras, CCC - Olímpia, Conectaí, CC - Louveira, CCC - Jaguariúna, Oxy Cidadão, Cidadão Mais BRASIL, Olhos de Águia, Minha Cidade, Onde Ir Cidades, Siga Cidades, Alerta Cidadão, ESPIA AQUI, App do Prefeito, ApPREF, Prefeitura mais digital, \#EuFaçoPOA, Boletim ao Mar, Consulta Protocolo, COR.Rio;

- Request for municipal services: Vitória Online, Portal Cidadão Campinas, MG App - Cidadão, Curitiba App, SP serviços, Blumenau Cidade Jardim, Prefeitura Na Mão, SP156, 1746 Rio, Prefeitura 24Horas, Jaraguá na Mão, Aracruz Online, Prefeitura de Jundiaí, SEI!, Rio+ Respeito Oficial, Monitora Jampa, USCS Frequência, Aplicativo Escolar, Niterói Rotativo, Detran.SP, HidroWeb;

- Reports of accusation/complaints: Coopera Simões Filho, eOuve, 156 Mobile Campinas, Central 156, Curitiba 156, 156Foz, 156 Sumaré, 156 SJC, Caraguatatuba 156, Fala Feira 156, 156 Limeira, Fiscalize Fortaleza;

- Reporting of public problems: Alô Governante, Alô Deputado, Alô Governador, Fala Cidadão, SAAE Agora Itabirito, Fogo Cruzado, OTT, SP+Segura, Colab, Conecta Jacareí, Denúncia Ambiente, App Barueri, Prefeitura de Eusébio, Prefeitura.com.vc, Transalvador, Vitória Online, Bairro Seguro, PBH APP, Pelas Ruas, Alerta Cidadão, Goiás Seguro, Jaguariúna (maus-tratos de animais), Aviso Polícia, CHAMAR 192, Salve Maria, PenhaS, SOS Mulher, Apoio Vítima, BemQuererMulher, MUSA;

- Municipal management tools: Vereador Reconhecido, Servidor.Rio, MarQPonto, Almoxarifado, Colabore, GovFácil, Elotech BI, App Gestão Cidades, Gestão na Mão, Atende.Net, App Pompéu, App Divinópolis, e-BI Inteligência Municipal, APP Cidadão - Franca, Atende.Net, GRP Mobile, SIGRC, Pública Mobile, Escola Virtual Gov, Licit Mais Brasil, Alerta Licitação, EngeGOV, Super Vereador, NeritPolítica, Politique, divoem, Cartão Qualidade, SisDC, Zul+, Gestão Mais BRASIL, Cidadão Mais BRASIL, Veredas Formativa, e-SUS AB Território, ACS - Agente Comunitário de Saúde, ACS Lite eSUS AB ePHealth, ePHealth ACS-Prefeituras, G-MUS Atenção Primária, Saúde Domiciliar;

- Health services: BoaConsulta, Busca Medicamentos Campinas, GliCampinas, Meu INSS, Dr.consulta, Doutor Hoje, G-MUS Saúde Cidadão, Agenda Fácil, Hora Marcada, Saúde Já, Doutore, Consultório, Saúde Mental, Saúde Fácil Goiânia, Saúde-Guarulhos, Saúde+ Uberlândia, Saúde Goiás+, Saúde-Valinhos, Saúde Suzano, Net Consulta, Saúde Na Mão SJC, Boraceia Saúde Online, Saúde Digital Ribeirão Preto, Meu digiSUS, Meu Info Saúde, Pronto mobile, Acesso Cidadão, Fala Saúde-Guarapuava, SissOnline Minha Saúde, Saude.rio, São Bernardo Saúde, e-Cidadão Saúde, De olho na consulta, Viconsus, Fast Cidadão;

- Identification and contracting of medical services from health professionals and nearby medical centers: Nossa Saúde, Doctoralia Brasil, Abertta Saúde, Guia de Saúde, Salut Saúde, Saves, Medical, Fácil Consultar, Mediconecta, EmConsulta, Nosso Médico, FastSaúde-ACS, Fast Cidadão, Mediktor, Dokter, Simples Dental, e-Raps, RENAME, ACE-Prefeituras ePHealth, Onde está o dinheiro da saúde?, Cuidar Idoso, Auditor Vetores, mobile AtendSaude Endemias, e-Visit@, evisita, Arbo App, Udi Sem Dengue, Sem Dengue, Patrulha da Dengue, Dengue Não, Valinhos Contra Dengue, Mosquito Zero, Mapa da Dengue, Uberaba Contra a Dengue, Combate Aedes; 
- Urban mobility: Giro MetrôRio, Metrô de São Paulo Oficial, Metrô DF, Ônibus.Rio, ÔnibusGV, floripanoponto, PartiuSBC, SiMRmtc, SigaBus Contagem, CittaMobi, Caxias Urbano, Cadê Meu Ônibus, Urmob, Wappa, Travessias, SOU, BluMob, Meu Buse, Urmob, Seletivo Fácil Santos, Transporte Coletivo, Meu Destino Vix, Vá de Ônibus, TAXI.RIO, SPTAXI, Taxi 2424, Vá de Táxi, URBS, Taxi62 Faixa Vermelha, Carona Solidária Fiocruz, TopBus+, 4Bus, Busbud, MOTO VIP, Bike Seguro, Bike Itaú, tembici, Riba Share, Grin Scooters, Movo, Lime, Beliive;

- Citizenship and civic issues: Chama o Vereador, Meu Vereador, Vereador Em Ação, Vereador Online, Alô Vereador Jandira, eCidadão, Câmara App, Legislador, Infoleg, Câmara Fácil, Fiscaliza Cidadão, Poder do Voto, Câmara Popular, Monitora, Brasil!, Nosso Mandato, Política+, Ação Política, Cidadão Online 4R, Govern, Zap Carioca, 1746 Rio, Governa Santa Rosa, Avise o Prefeito, Prefeitura e Você, EcoRodovias, Participa Campinas, LeisMunicipais, Politize!, Politicometro, Corrida Eleitoral Online, Ranking dos Políticos, Eu Parlamentar, Conheça Seu Candidato, Votodata, Candidato Legal!, Pesquisa Eleitoral App, Teste Político, Minha Cidade, Planet App, SmartCity, Mudamos+;

- Weather alerts: AlertaBlu, AlertaRio, AlertaVale, Emergência RJ, Alerta Rio Branco, Mau tempo!, SOS Chuva, Weather Alerts Ultimate, Alerta DCNit, Vai Dar Praia, CEM, ALERTA199, SenseApp, Defesa Civil - Ouro Preto, Alerta DCNit, App Defesa Civil de Aimorés, Sistema de Alertas Rolante-RS; and

- Blitz, radar and accident communication: LeisecaMaps, LeiSecaRJ, Blitz Alerta, Blitz Salvador, Detector de Polícia, KoDinMaps, Radardroid, Ray.Radar, Radares, CamSam, Radares Brasil, Glob, AmiGO, Sem Parar.

These startups aim to facilitate citizens' access to public services and develop crowd-based solutions, i.e., use the wisdom of the crowds, as well as the decentralized information held by these citizens, to increase efficiency in public management. Its diffusion among the municipalities can contribute to the advancement in the quality and efficiency of public services.

Herein, however, it should be noted that the comparison with the initiatives identified at the international level shows that there are some important areas in which similar initiatives have not been found in the national territory - emphasis on the rental of machinery and equipment between different entities of the federation and for the development of $\mathrm{C} 2 \mathrm{C}$ solutions. Therefore, there is space for the creation of specialized applications for sharing public assets between Brazilian municipalities that encourage the development of decentralized solutions from citizens to their own citizens.

\subsection{Descriptive analysis}

The use of new digital technologies by Brazilian municipalities is characterized by the tabulation of some descriptive statistics, which seek to measure the most relevant characteristics.

Table 1 shows that $87 \%$ of Brazilian municipalities have remote customer service through the internet. However, the availability of these services varies greatly according to the size of the municipality and the region in which it is located. The largest municipalities in the Midwest, North and South regions are those that are in the best relative positioning. It is observed that the proportion of smaller municipalities, mainly in the North and Northeast regions, which provide services to the public at a distance, through the internet, is lower than that observed for the other regions. For example, only $70 \%$ of the municipalities with up to 5,000 inhabitants in the Northeast region provide this service. 

DISCRIMINATED ACCORDING TO POPULATION SIZE CLASSES IN THE MUNICIPALITIES (2014)

\begin{tabular}{|c|c|c|c|c|c|c|}
\hline & Brasil & North & Northeast & Southeast & South & Midwest \\
\hline Total & $87 \%$ & $80 \%$ & $80 \%$ & $92 \%$ & $93 \%$ & $91 \%$ \\
\hline Up to 5.000 & $87 \%$ & $77 \%$ & $70 \%$ & $90 \%$ & $93 \%$ & $93 \%$ \\
\hline From 5.001 to 10.000 & $86 \%$ & $73 \%$ & $77 \%$ & $93 \%$ & $91 \%$ & $87 \%$ \\
\hline From 10.001 to 20.000 & $86 \%$ & $78 \%$ & $80 \%$ & $90 \%$ & $95 \%$ & $85 \%$ \\
\hline From 20.001 to 50.000 & $88 \%$ & $82 \%$ & $84 \%$ & $91 \%$ & $94 \%$ & $95 \%$ \\
\hline From 50.001 to 100.000 & $91 \%$ & $86 \%$ & $85 \%$ & $94 \%$ & $96 \%$ & $100 \%$ \\
\hline From 100.001 to 500.000 & $95 \%$ & $100 \%$ & $92 \%$ & $94 \%$ & $94 \%$ & $100 \%$ \\
\hline More than 500.000 & $95 \%$ & $100 \%$ & $91 \%$ & $94 \%$ & $100 \%$ & $100 \%$ \\
\hline
\end{tabular}

Source: Basic Municipal Information Survey, IBGE.

The analysis of the services available on the internet (Tables 2 and 3) mainly shows that the new communication technologies are actually still little used by municipalities to provide services to the population. The vast majority of municipalities have pages on the Internet, but the services provided are limited. For example, only $1 \%$ of the municipalities allow the enrollment of students and the scheduling of consultations in the public health network to be carried out through the internet.

The low volume of digitalization of services provided by local governments shows the existence of a high scope for the adoption of new digital technologies and sharing applications, with a view to facilitating the population's access to public services. The adoption of policies to encourage the emergence of private applications, specialized in providing specific services and interacting with society, can contribute to reducing costs and increasing the quality and efficiency of public services provided. The emergence of specialized digital platforms can facilitate citizens' access to public services (Accenture, 2016; Cherry \& Pidgeon, 2018). In addition, it can also promote the decentralization and co-creation of these services, through the active participation of the population in the identification, proposition and implementation of public policies aimed at solving collective problems.

Taking into account the existing limitation on internet access, the IFGF is used to measure municipal management practices. This index is prepared by the Federation of Industries of the State of Rio de Janeiro (FIRJAN) based on the fiscal results reported by the city halls, made available annually by the National Treasury Secretariat (STN). The IFGF is composed of four indicators: Autonomy, Personnel Expenses, Liquidity and Investments. Each indicator has a weight of $25 \%$ in the final index.

The great advantage presented by the IFGF is the possibility of comparing municipalities, as it is a simple indicator that covers the different dimensions that characterize municipal public finances, and might; therefore, be used to verify how the digitization of public services affects fiscal performance. The IFGF varies between 0 and 1, being classified into four categories: Concept A (management of excellence), IFGF higher than 0.8; Concept B (good management), IFGF between 0.6 and 0.8 ; Concept $\mathrm{C}$ (management in difficulty), IFGF between 0.4 and 0.6 ; Concept D (critical management), IFGF between 0 and 0.4 . In this way, it is possible to directly compare the fiscal situation of the municipalities. 
RAP | Sharing economy and public governance

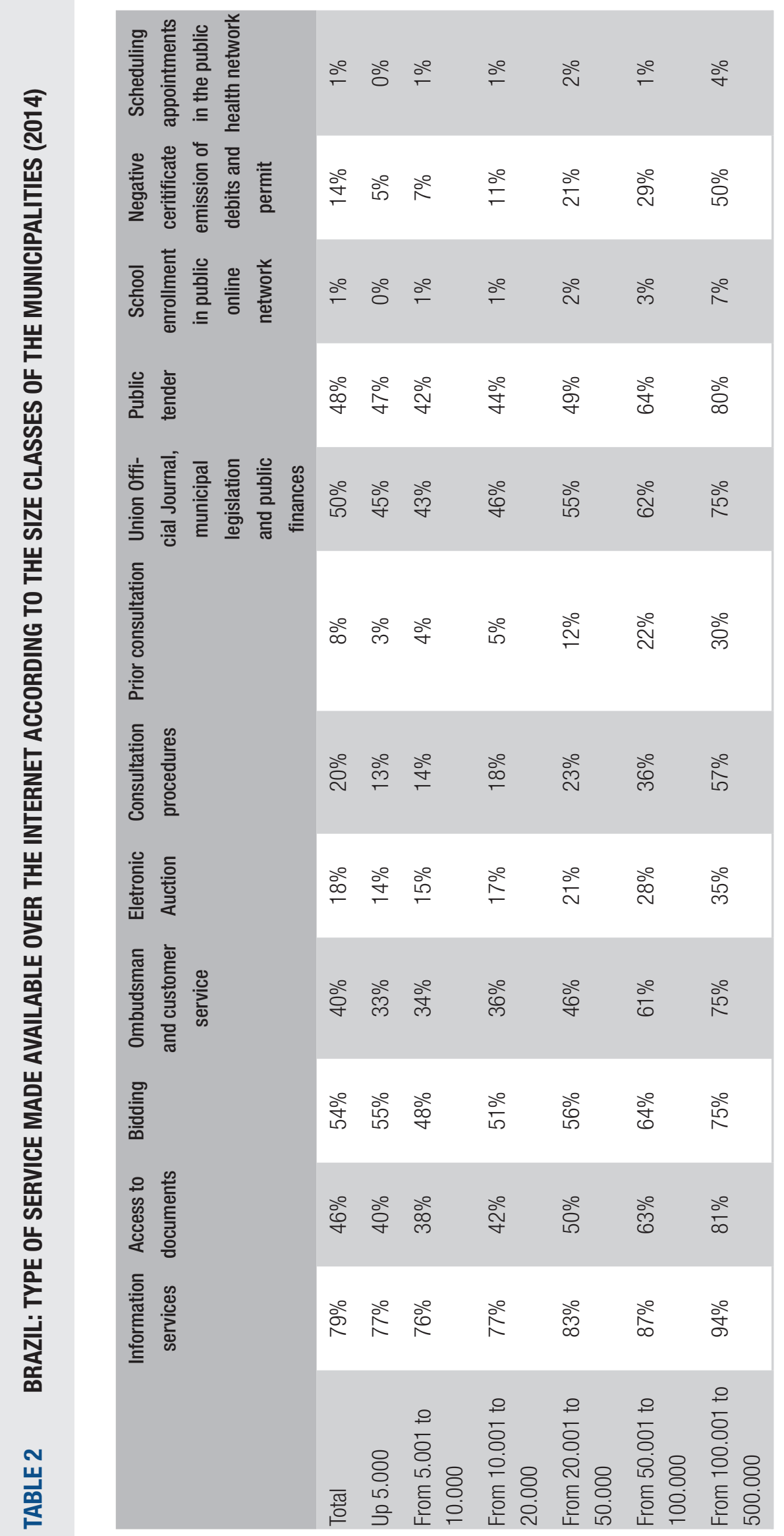


RAP | Sharing economy and public governance

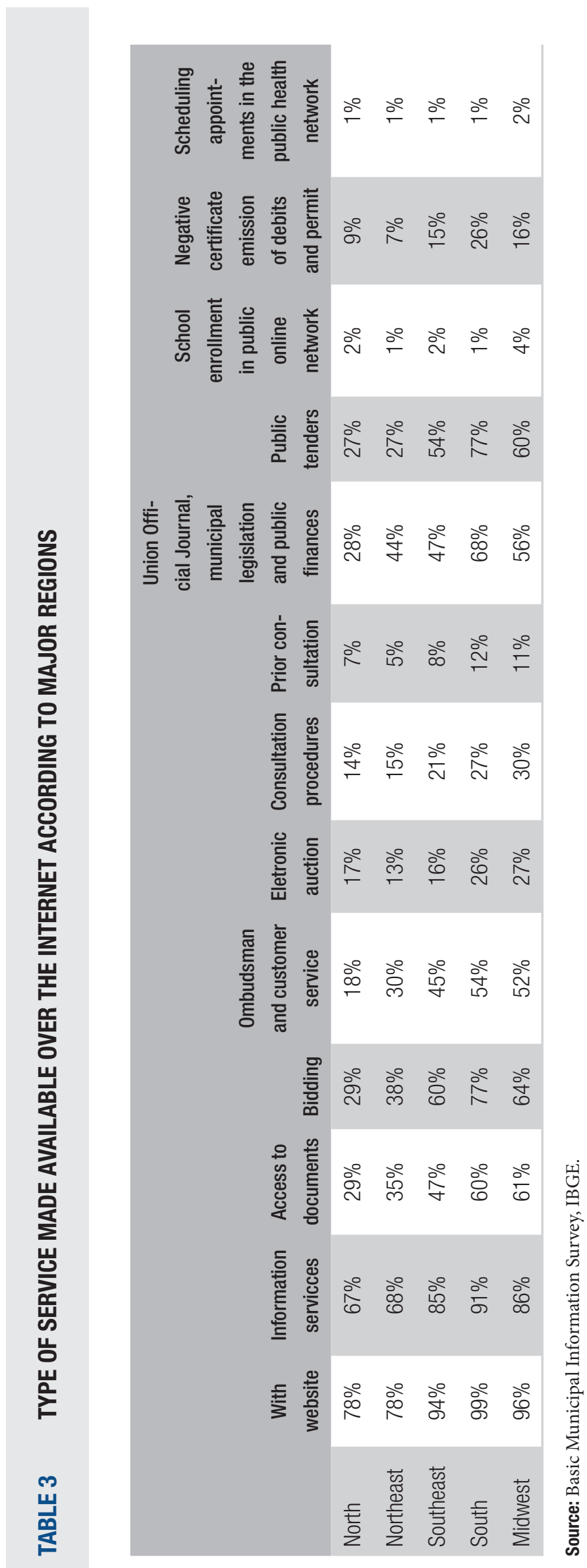

Brazilian Journal Of PUblic administration ｜ Rio de Janeiro 54(5):1207-1238, Sept. - Oct. 2020 
Table 4 summarizes the IFGF of Brazilian municipalities. Since 2009, most municipalities have been classified as having a good management concept, which is mainly explained by the reduction of municipalities with management in difficulty and critical management. The number of municipalities with excellent management remains relatively low, with no increase in the number of municipalities classified in this category.

\section{TABLE 4 EVOLUTION OF THE IFGF (2005-2016)}

$\begin{array}{llllllllllllll} & \mathbf{2 0 0 5} & \mathbf{2 0 0 6} & \mathbf{2 0 0 7} & \mathbf{2 0 0 8} & \mathbf{2 0 0 9} & \mathbf{2 0 1 0} & \mathbf{2 0 1 1} & \mathbf{2 0 1 2} & \mathbf{2 0 1 3} & \mathbf{2 0 1 4} & \mathbf{2 0 1 5} & \mathbf{2 0 1 6} \\ \text { Concept A } & 142 & 198 & 198 & 260 & 316 & 435 & 503 & 568 & 654 & 556 & 296 & 431 \\ \text { Concept B } & 2.105 & 2.282 & 2.637 & 2.618 & 2.961 & 3.002 & 3.147 & 3.296 & 3.413 & 3.521 & 3.615 & 3.741 \\ \text { Concept C } & 2.214 & 2.238 & 2.311 & 2.345 & 2.084 & 1.972 & 1.801 & 1.612 & 1.433 & 1.430 & 1.583 & 1.289 \\ \text { Concept D } & 825 & 615 & 351 & 261 & 125 & 100 & 57 & 36 & 17 & 24 & 27 & 10\end{array}$

Source: Adapted from FIRJAN.

\subsection{Estimated regression}

According to Gujarati (2011), the regression analysis identifies whether there is a dependence relationship on one variable, the dependent variable, in relation to one or more variables, the exploratory variables, which can be formally expressed through the equation

$$
Y=X \beta+u
$$

at which $Y$ being the dependent variable, in the present case the IFGF; $X$ is a vector of exploratory variables; $\beta$ is the estimated parameter; and $u$ is the error term.

Vector $X$ consists of a set of eight variables that identify the degree of computerization of municipal administrations (mail; fax; newspapers; internet; telephone; exclusive telephone; networked computers; intranet); fourteen variables related to the provision of information and the digitization of services provided by local governments (active page; information services and news; access to documents and forms; tenders; ombudsman; electronic auction; consultation of processes; prior consultation of the provisional permit; Official Gazette , municipal legislation and public finances; public tenders; school enrollment in the public online network; negative debit certificate; scheduling of consultations in the public health network; digital inclusion policy); and three control variables (population logarithm; CLT proportion; statutory proportion), added to identify the effect of the size of the municipality and the degree of professionalization of municipal management on fiscal performance.

The regression model is estimated using the MQO method, with data made available by IBGE for 2014, for 5,465 municipalities, based on data from MUNIC. The model aims to assess the impact 
of new digital technologies on the fiscal management of local governments. The regression model is the chosen tool, as it allows to verify the effect of the digitalization of each municipal service on fiscal performance, providing clarifying information on the gains that can be obtained from the adoption of a policy to encourage the use of sharing applications in local governments.

The effect of the digitization of each service on fiscal performance is identified by applying the hypothesis test, namely:

$$
\text { Teste } t=\frac{\hat{\beta}-\beta_{i}}{e p(\beta)} \text {, }
$$

at which $\hat{\beta}$ being the value found for the estimated parameter and ep $(\beta)$ its respective standard error.

As the null hypothesis tested is that the coefficient $\hat{\beta}$ is equal to zero, equation (2) collapses in the following equation:

$$
\text { Teste } t=\frac{\hat{\beta}}{e p(\beta)} \text {, }
$$

if the value found for the t-test is higher than the table (for normal distribution) with n-k degrees of freedom, with $\mathrm{n}$ being the number of municipalities and $\mathrm{k}$ being the number of exploratory variables, the alternative hypothesis is corroborated. Otherwise, it is not possible to reject the null hypothesis. In addition, if the value found for the t-test is higher than the table and the estimated coefficient shows a negative sign, there are indications that the digitalization of the service compromises the municipality's fiscal performance.

As recommended by Gujarati (2011), the determination coefficient, the F test, the variance inflation factor and the Breusch-Pagan test are applied to identify whether the estimated model can be used to make statistical inferences.

Table 5 presents the results obtained for the estimated regression. Regarding the provision of services by local governments via the Internet, only the binary variables that identify the presence of fax and telephone are not statistically significant. The rest, variables, in an absolute majority, contribute to the improvement in the fiscal performance of the municipalities, despite the variable variable of digital inclusion presenting a value close to zero. The greater presence of newspapers, internet, intranet, exclusive telephone, networked computers and active page contributes to better fiscal performance, despite the estimated coefficients being close to zero. These results show the positive effects generated by the computerization of local governments, in terms of improving the fiscal management of municipalities. 

THE INTERNET (2014)

\begin{tabular}{|c|c|c|c|c|c|}
\hline Variável & Coef." & Std. \#\# & Variável & Coef. & Std. \\
\hline Mail & $0,018^{\star \star}$ & 0,009 & Eletronic auction & $-0,014^{\star \star}$ & 0,003 \\
\hline Fax & 0,000 & 0,003 & Consultation procedures & $0,008^{\star *}$ & 0,003 \\
\hline Journals & $0,021^{\star *}$ & 0,003 & $\begin{array}{l}\text { Prior consultation (provisional } \\
\text { permit) }\end{array}$ & $0,008^{*}$ & 0,005 \\
\hline Internet & $0,023^{\star *}$ & 0,003 & $\begin{array}{l}\text { Union Official Journal, municipal } \\
\text { legislation and public finances }\end{array}$ & $-0,009^{\star \star}$ & 0,003 \\
\hline Telephone & 0,000 & 0,004 & Public tenders & $0,031^{\star *}$ & 0,003 \\
\hline Exclusive telephone & $0,008^{*}$ & 0,004 & $\begin{array}{l}\text { School Enrollment in Public online } \\
\text { network }\end{array}$ & 0,004 & 0,010 \\
\hline \multirow[t]{2}{*}{$\begin{array}{l}\text { Networked computers } \\
\text { Intranet }\end{array}$} & $0,007^{\star *}$ & 0,002 & Negative certification of debits & $0,046^{\star *}$ & 0,004 \\
\hline & $0,016^{\star *}$ & 0,003 & $\begin{array}{l}\text { Scheduling appointments in the } \\
\text { public health network }\end{array}$ & $-0,03^{\star *}$ & 0,013 \\
\hline Active page & $0,028^{\star *}$ & 0,004 & Digital inclusion policy & 0,000 & 0,003 \\
\hline $\begin{array}{l}\text { News and information } \\
\text { service }\end{array}$ & $0,016^{\star *}$ & 0,004 & Population Log & $-0,002$ & 0,001 \\
\hline Documents access and Forms & 0,002 & 0,003 & CLT propotion & $0,095^{\star *}$ & 0,008 \\
\hline Biddings & $0,011^{\star *}$ & 0,003 & Proportion of statutory & $0,146^{\star *}$ & 0,008 \\
\hline Ombudsmand & $0,019^{* *}$ & 0,003 & Constant & $0,487^{* *}$ & 0,014 \\
\hline R2 & 0,3273 & & & & \\
\hline F test & 105,87 & & & & \\
\hline Breusch-Pagan & 16,25 & & & & \\
\hline
\end{tabular}

Notes: ${ }^{*}$ Significant at the $95 \%$ confidence level.

* Significant at the $90 \%$ confidence level. The variance inflation factor shows the absence of multicollinearity.

* Estimated coefficient.

\#\# Standard error.

Source: Elaborated by the authors.

The estimated regression also checks whether the provision of services through the digital page of local governments contributes to the improvement in fiscal performance. With the exception of access to documents and forms and school enrollment in the public online network, all other binary variables are significant. However, electronic trading, Union Official Journal, municipal legislation and public finances and scheduling appointments in the public health network show a negative sign, indicating that the provision of these services from the sites results in worse fiscal performance. In addition, digital inclusion policy, consultation of processes and prior consultation (provisional license) show estimated coefficients close to zero. 
The negative results detected for these variables show the challenges imposed by the new digital technologies to municipal management. The distinct characteristics presented by the entities that make up each local government mean that the sharing and computerization of services can generate several management problems (Accenture, 2016). These services are related, for example, to the need to standardize routines and procedures, to train public officials and to eliminate coordination problems. It is necessary to monitor managers in the development of solutions related to the provision of these services.

The negative coefficients are verified mainly for those services that demand greater interaction with citizens. On the other hand, positive signs are observed mainly for services that demand less interaction with citizens. Thus, the biggest problems of local management, related to the use of new digital technologies, are observed in services that involve greater interaction with users. This is a clearly favorable evidence to the argument that municipalities are currently not prepared to provide public services through digital tools. It can also indicate that the creation of tools that increase accessibility to public services results in greater interaction with users, which demands more time spent on serving users, increasing costs and contributing to the deterioration in the fiscal situation of municipalities.

It is worth noting that the development of new tools that facilitate interaction with users is one of the main areas of expansion of the Sharing economy. The evaluation and self-regulatory mechanisms present on these platforms can help to reduce the problems of coordination and interaction with users currently faced by Brazilian municipal managers (Botsman, 2017; Möhlmann \& Geissinger, 2018; Sundararajan, 2016).

Regarding the control variables, the population log is not significant, indicating that management problems are not related to the size of the municipality. On the other hand, the variables proportion of CLT workers and proportion of statutory workers are statistically significant, showing the need to control the effect of the qualification of employees on the fiscal performance of the municipalities.

In summary, the results found demonstrate that the municipalities face several problems related to the digitalization of public services. The arguments presented here corroborate the literature of Sharing economy: the adoption of sharing applications and instruments that enable direct interaction between citizens can have a positive effect on the provision of public services, proving to be beneficial for municipalities (Accenture, 2016; Chasin \& Scholta, 2015; Ganapati \& Reddick, 2018; Kirchherr et al., 2017; Meilă, 2018; Turban et al., 2018). It is justified, therefore, the fact that these areas are among those that observe greater emergence of Sharing economy applications aimed at public management at the national level. In a certain aspect, the emergence of these applications is already a response by public managers to these problems. 


\section{FINAL CONSIDERATIONS}

The Sharing economy identifies a set of activities that are not necessarily restricted to the promotion of resource sharing, having as a common denominator the feasibility of access to goods and services through new digital technologies.

These technologies are used to create virtualized markets, consisting of specific rules for online interaction which aim to offer a feasible answer to the tragedy of common goods and the presence of opportunistic agents, enabling the offer of public goods through the development of specialized digital applications and platforms that encourage decentralized and direct interaction between citizens $(\mathrm{C} 2 \mathrm{C})$, citizens and government $(\mathrm{C} 2 \mathrm{G})$, different entities and spheres of government $(\mathrm{G} 2 \mathrm{G})$ and between government and private companies (G2B).

This article uses the documentary research technique to conduct a survey of the sharing applications aimed at the public sector that have recently emerged at the national and international levels. Descriptive data analysis and regression estimation are used to characterize internet access in the national territory and to identify the effect of digitalization of public services on the fiscal performance of Brazilian municipalities.

The survey of Sharing economy applications, shown in section 2, showed that from the 1990s, with the advancement in communication technologies (internet, smartphones and applications), sharing startups specialized in facilitating access to goods began to emerge and services. In this way, the Sharing economy has become increasingly transversal and relevant. Its advance is probably one of the main sources of innovation in the first two decades of the 21st century.

The data presented in section 3 show that the advancement of the Sharing economy creates important constraints and opportunities for local governments. It demands a change in attributions and creates new challenges for local governments. It also provides: 1) more efficient coordination between the spheres and entities that make up local governments (G2G);2) greater decentralization and access by citizens to public decisions (G2C); 3) the development of decentralized solutions (C2C) for public order problems, reducing the need for government intermediation; and 4) the emergence of G2B applications, specialized in providing solutions that promise to increase the efficiency of the public sector, by reducing the underutilization of assets and more efficient coordination within and between federal entities.

Subsection 4.1 shows that the use of Sharing economy applications is a reality in many Brazilian municipalities. The survey carried out showed the high degree of diversification in the contributions of the Sharing economy to improve the management of Brazilian municipalities. These contributions range from applications specialized in providing information and scheduling services to applications that encourage citizen participation and the identification and proposition of solutions to public problems.

In subsection 4, the analysis carried out also indicated that there is still room for the emergence of sharing applications in activities such as: 1 ) coordination between local governments; 2 ) digitalization of local governments (as evidenced by the data compiled in subsection 4.2); 3) reduction in the underutilization of public assets; and 4) development of decentralized solutions (C2C).

The estimated regression to verify how the digitalization of public services definitely influences the fiscal performance of municipalities, measured from the IFGF (subsection 4.3), shows that the provision of public attendance services through the internet contributes significantly to the improvement in fiscal 
management indicators. Paradoxically, the computerization of public services, especially those that demand greater interaction with users, has a negative effect on the fiscal performance of municipalities. This result is favorable to the argument that public managers are not able to exploit the advantages presented by digital technologies, succumbing in the face of new challenges. They lack initiatives, instruments and public policies that help them to modernize the services, routines and procedures performed, a space that can be occupied by new sharing applications.

Indeed, the evidence found throughout the article shows that the Sharing economy is transforming the way governments manage existing infrastructure and how it is used. They also indicate that there is space for the development of virtualized solutions and for the emergence of applications specialized in the provision of public goods.

Sharing economy applications allow more decentralized interaction and self-regulation by users, thus being able to help public managers to face the management and coordination difficulties currently present. The development of new rules for access to public goods encapsulated in specialized digital applications and platforms represents a fertile field of research, with high growth potential and which may significantly contribute to the advancement of the public sector.

Municipal public managers also lack policies responsible for promoting greater awareness of: 1) the private applications that currently exist; 2 ) the gains that can be obtained by using these applications; and 3) the possibilities for adopting sharing initiatives in local governments. There is also a need for public policies that encourage the development of sharing platforms in local governments, especially policies to foster entrepreneurship, aimed at developing applications specialized in the sharing, co-creation and decentralization of public assets and services, and that facilitate the realization of partnerships between public and private initiatives.

Undoubtably, further studies that seek to advance on themes such as: identification of new possibilities for using the Sharing economy in the public sector; survey of difficulties and challenges faced in the use of sharing applications in the public sector as well as proposing solutions, adaptations and institutional modifications that enhance the contribution of the Sharing economy to local management obtained in this study are stimulated. 


\section{REFERENCES}

Accenture. (2016). Is ownership obsolete? Share your way togovernment innovation. Retrieved from https:// www.accenture.com/t20160224t161639z__w__/ us-en/_acnmedia/accenture/next-gen/insightsharing-economy/documents/accenture-sharingeconomy-letter.pdf

Aguinis, H., \& Lawal, S. O. (2013). eLancing: a review and research agenda for bridging the science-practice gap. Human Resource Management Review, 23(1), 6-17.

Albinsson, P. A., \& Perera, B. Y. (2012). Alternative marketplaces in the 21 st century: Building community through sharing events. Journal of consumer Behaviour, 11(4), 303-315.

Allessie, D., Sobolewski, M., \& Vaccari, L. (2019). Blockchain for digital government: An assessment of pioneering implementations in public services. (JCR Science for policy report). Seville, Spain: European Commission, Joint Research Centre.

Aslam, A., \& Shah, M. A. (2017). Taxation and the peer-to-peer economy. Washington, DC: International Monetary Fund.

Axelrod, Robert (1984). The evolution of cooperation. New York, NY: Basic Books.

Bauwens, M. (2006). The political economy of peer production. post-autistic economics review, 37, 33-44.

Benkler, Y. (2002). Coase's penguin, or, Linux and the nature of the firm. The Yale Law Journal, 112(3), 369-446.

Benkler, Y. (2006). The wealth of networks: how social production transforms markets and freedom. London, UK: Yale University Press.

Bond, A. T. (2015). An app for that: local governments and the rise of the sharing economy. Notre Dame $L$. Rev. Online, 90(2), 77-96.

Botsman, R. (2017). Who can you trust? How technology brought us together and why it might drive us apart. London, UK: Hachette.

Botsman, R., \& Rogers, R. (2009). O que é meu é seu: como o consumo colaborativo vai mudar o nosso mundo. Porto Alegre, RS: Bookman.

Bradshaw, C. J., \& Brook, B. W. (2014). Human population reduction is not a quick fix for environmental problems. Proceedings of the National Academy of Sciences, 111(46), 16610-16615.

Brescia, R. H. (2016). Regulating the sharing economy: New and old insights into an oversight regime for the peer-to-peer economy. Neb. L. Rev., 95(1), 87-145.

Bull, G. (2010). The always-connected generation. Learning \& Leading with Technology, 38(3), 28-29.

Cannon, S., \& Summers, L. H. (2014). How Uber and the sharing economy can win over regulators. Harvard Business Review, 13(10), 24-28.

Carter, L., \& Ubacht, J. (2018). Blockchain applications in government. In Proceedings of the 19th Annual International Conference on Digital Government Research: governance in the data age, New York, NY, USA.

Chasin, F., \& Scholta, H. (2015). Taking peer-topeer sharing and collaborative consumption onto the next level-new opportunities and challenges for e-government. In Proceedings of the 23rd European Conference on Information Systems (ECIS), Münster, Germany.

Chen, L. (2015, December 04). At $\$ 68$ billion valuation, Uber will be bigger than GM, Ford, and Honda. Forbes.

Cherry, C. E., \& Pidgeon, N. F. (2018). Is sharing the solution? Exploring public acceptability of the sharing economy. Journal of cleaner production, 195, 939-948.

Clark, B. Y., Larco, N., \& Mann, R. F. (2017, August). The impacts of autonomous vehicles and e-commerce on local government budgeting and finance. Portland, Orgen: University of Oregon. Retrieved from https:// ssrn.com/abstract $=3009840$

Clarke, A.; Lindquist, E. A.; Roy, J. (2017). Understanding governance in the digital era: an agenda for public administration research in Canada. Canadian Public Administration, 60(4), 457-476.

Codagnone, C., Abadie, F., \& Biagi, F. (2016). The future of work in the 'sharing economy'. Market efficiency and equitable opportunities or unfair precarisation? (JRC Science for Policy Report). Seville, Spain: Institute for Prospective Technological Studies. 
Cohen, M., \& Sundararajan, A. (2015). Selfregulation and innovation in the peer-to-peer sharing economy. U. Chi. L. Rev. Dialogue, 82(1), 116-133.

Coleman, C. (2013). Total workplace transformsfederal office space. Retrieved from https://gsablogs.gsa. gov/innovation/2013/11/19/gsas-total-workplacecreates-a-21st-centuryworkplace-designed-to-savemoney-and-increase-efficiency-and-productivity/

Conselho Administrativo de Defesa Econômica. (2018). Processo Administrativo $n$. 08700.006964/2015-71. Brasília, DF: Autor.

Cramer, J., \& Krueger, A. B. (2016). Disruptive change in the taxi business: the case of Uber. American Economic Review, 106(5), 177-82.

Dellarocas, C. (2010). Designing reputation systems for the social web. (Research Paper Series, No. 201018). Boston, Massachusetts: Boston University School of Management.

Dubois, E., Schor, J., \& Carfagna, L. (2014, April). Connected consumption: a sharing economy takes hold. Rotman Management, 1, 50-55.

Eckhardt, G. M., \& Bardhi, F. (2015, January 28). The sharing economy isn't about sharing at all. Harvard business review.

Erickson, K., \& Sørensen, I. (2016). Regulating the sharing economy: introduction to the special issue. Internet Policy Review, 5(2), 1-15.

Esteves, L. A. (2015). Rivalidade após entrada: o impacto imediato do aplicativo Uber sobre as corridas de táxi porta-a-porta (Documento de trabalho, 003/2015). Brasília, DF: Conselho Administrativo de Defesa Econômica.

Federação das Indústrias do Estado de Rio de Janeiro. (2017). IFGF 2017: Índice FIRJAN de Gestão Fiscal. Rio de Janeiro, RJ: Autor. Retrieved from: https://www.firjan.com.br/ifgf/downloads/

Frenken, K., \& Schor, J. (2017, June). Putting the sharing economy into perspective. Environmental Innovation and Societal Transitions, 23, 3-10.

Ganapati, S. (2015). Using mobile apps in government. Washington, DC: IBM Center for The Business of Government.
Ganapati, S., \& Reddick, C. G. (2018). Prospects and challenges of sharing economy for the public sector. Government Information Quarterly, 35(1), 77-87.

Gansky, L. (2010). The mesh: why the future of business is sharing. New York, NY: Penguin Random House.

Gujarati, D. N.; Porter, D. C. (2012). Econometria Básica. (5ª Ed.). São Paulo, SP: AMGH Editora.

Hamari, J., Sjöklint, M., \& Ukkonen, A. (2016). The sharing economy: why people participate in collaborative consumption. Journal of the association for information science and technology, 67(9), 20472059.

Hardin, G. (1968). The tragedy of the commons. Science, 162(3859), 1243-1248.

Harris, B. (2017). Uber, lyft, and regulating the sharing economy. Seattle UL Rev., 41(1), 269-285.

Heinrichs, H. (2013). Sharing economy: a potential new pathway to sustainability. GAIA-Ecological Perspectives for Science and Society, 22(4), 228-232.

Hong, S.; Lee, S. (2018). Adaptive governance and decentralization: evidence from regulation of the sharing economy in multi-level governance. Government Information Quarterly, 35(2), 299-305.

Hong, S.; Ryu, J. (2019). Crowdfunding public projects: Collaborative governance for achieving citizen co-funding of public goods. Government Information Quarterly, 36(1), 145-153.

Hou, H. (2017). The application of blockchain technology in E-government in China. In Proceedings of the 26th International Conference on Computer Communication and Networks (pp. 1-4), Honolulu, USA.

Janssen, M., \& Joha, A. (2006, December). Governance of shared services in public administration. In Proceedings of the Americas Conference on Information Systems 2006, (pp. 2306-2314), Acapulco, Mexico.

Janssen, M., Konopnicki, D., Snowdon, J. L., \& Ojo, A. (2017). Driving public sector innovation using big and open linked data (BOLD). Information systems frontiers, 19(2), 189-195. 
Jun, M. S. (2018). Blockchain government-a next form of infrastructure for the twenty-first century. Journal of Open Innovation: Technology, Market, and Complexity, 4(7), 1-12.

Kaplan, D. (2014, January 30). Collaboratif - Trois questions à... Daniel Kaplan, Fing. Alliancy. Retrieved from https://www.alliancy.fr/article/ industrie/2014/01/30/collaboratif-trois-questionsa-daniel-kaplan-fing

Kirchherr, J., Reike, D., \& Hekkert, M. (2017, December). Conceptualizing the circular economy: an analysis of 114 definitions. Resources, Conservation and Recycling, 127, 221-232.

Koopman, C., Mitchell, M. D., \& Thierer, A. D. (2015, May). The sharing economy and consumer protection regulations: the case for policy change. The Journal of Business, Entrepreneurship \& Law, 8(2), 529-545.

Lei $n^{\circ}$ 13.640, de 26 de março de 2018. (2018). Altera a Lei no 12.587, de 3 de janeiro de 2012, para regulamentar o transporte remunerado privado individual de passageiros. Brasília, DF: Diário Oficial da União.

Lessig, L. (2008). Remix: making art and commerce thrive in the hybrid economy. New York, NY: The Penguin Press.

Linders, D. (2012). From e-government to wegovernment: defining a typology for citizen coproduction in the age of social media. Government Information Quarterly, 29(4), 446-454.

Lloyd, W. F. (1833). Two lectures on the checks to population. Oxford, UK: Oxford University Press.

Lyons, T., Courcelas, L., \& Timsit, K. (2018, December 07). Blockchain for government and public services (Thematic Report). Paris, France: The European Union Blockchain Observatory \& Forum.

Marconi, M. D. A., \& Lakatos, E. M. (2002). Técnicas de pesquisa (Vol. 2, pp. 35-36). São Paulo, SP: Atlas.

Marshall, P. (2015, August 03). The sharing economy: is it really different from traditional business? SAGE Business Researcher. Retrieved from http:// businessresearcher.sagepub.com/sbr-1645-967382690068/20150803/the-sharing-economy\#

Meilă, A. D. (2018). Sustainable urban mobility in the sharing economy: digital platforms, collaborative governance, and innovative transportation. Contemporary Readings in Law and Social Justice, 10(1), 130-136.

Mendes, F. S., \& Ceroy, F. M. (2015). Economia compartilhada e a politica nacional de mobilidade urbana: uma proposta de marco legal (Texto para Discussão no 185). Brasília, DF: Núcleo de Estudos e Pesquisas/CONLEG/Senado.

Möhlmann, M., \& Geissinger, A. (2018). Trust in the sharing economy: platform-mediated peer trust. Cambridge Handbook of the Law of the Sharing Economy. Cambridge, MA: Cambridge University Press.

Moon, M. J., Lee, J., \& Roh, C.-Y. (2014). The evolution of internal IT applications and e-government studies in public administration: Research themes and methods. Administration \& Society, 46(1), 3-36.

Mulcahy, D. (2016). The gig economy: the complete guide to getting better work, taking more time off, and financing the life you want. New York, NY: Amacom.

Nota Técnica no 39/2018/DEE/CADE. (2018). Ato de concentração referente à operação de transferência de autorização para prestação de serviços de transporte interestadual de passageiros da Gardênia para a UTIL. Análise de diferença de médias de linhas, passageiros e descontos dos períodos pré e pós-operação por mínimos quadrados ordinários. Não se encontrou, de forma consistente, qualquer mudança de padrão de atuação que possa ter decorrido da referida operação. Brasília, DF: Conselho Administrativo de Defesa Econômica.

Ojo, A.; Adebayo, S. (2017). Blockchain as a next generation government information infrastructure: A review of initiatives in D5 countries. In A. Ojo, \& J. Millard (Eds.), Government 3.0-Next Generation Government Technology Infrastructure and Services (pp. 283-298). Cham, Germany: Springer.

Ølnes, S.; Ubacht, J.; Janssen, M. (2017). Blockchain in government: Benefits and implications of distributed ledger technology for information sharing. Amsterdam, The Netherlands: Elsevier.

Ostrom, E., Burger, J., Field, C. B., Norgaard, R. B., \& Policansky, D. (1999). Revisiting the commons: local lessons, global challenges. Science, 284(5412), 278-282. 
Puschmann, T. \& Alt, R. (2016). Sharing economy. Business \& Information Systems Engineering, 58(1), 93-99.

Rauch, D., \& Schleicher, D. (2015). Like Uber, but for local governmental policy: the future of local regulation of the 'sharing economy'. (Research Paper, 15-01). Fairfax, Virginia: George Mason University.

Rifkin, J. (2016). Sociedade com custo marginal zero. São Paulo, SP: M. Books do Brasil Editora.

Resende, G. M., \& Lima, R. C. A. (2018). Efeitos concorrenciais da economia do compartilhamento no Brasil: a entrada da Uber afetou o mercado de aplicativos de táxi entre 2014 e 2016? (Documento de trabalho, n. 001/2018). Brasília, DF: Conselho Administrativo de Defesa Econômica.

Resolução no 148, de 2 de agosto de 2019. (2019). Altera a Resolução CGSN no 140, de 22 de maio de 2018, que dispõe sobre o Regime Especial Unificado de Arrecadação de Tributos e Contribuições devidos pelas Microempresas e Empresas de Pequeno Porte (Simples Nacional). Brasília, DF: Diário Oficial da União. Retrieved from http://www.in.gov. $\mathrm{br} / \mathrm{web} / \mathrm{dou} /-/$ resolucao-n-148-de-2-de-agostode-2019-209517410

Rivera, R., Robledo, J. L., Larios, V. M., \& Ávalos, J.M. (2017). How digital identity on blockchain can contribute in a smart city environment. In Proceedings of 2017 International Smart Cities Conference. (pp. 1-4), Wuxi, China.

Schor, J. B. (2016, October). Debating the sharing economy. Journal of Self-Governance \& Management Economics, 4(3), s.p.

Schor, J. B., Fitzmaurice, C., Carfagna, L. B., Attwood-Charles, W., \& Poteat, E. D. (2016). Paradoxes of openness and distinction in the sharing economy. Poetics, 54, 66-81.

Selloni, D. (2017). New forms of economies: sharing economy, collaborative consumption, peer-to-peer economy. In D. Selloni. (Ed.), CoDesign for PublicInterest Services (pp. 15-26). Cham, Germany: Springer.

Smith, R., \& Leberstein, S. (2015). Rights on demand: Ensuring workplace standards and worker security in the on-demand economy. Washington, DC: National Employment Law Project.
Stemler, A. (2017a). Feedback loop failure: Implications for the self-regulation of the sharing economy. Minn. JL Sci. \& Tech., 18(2), 673-712.

Stemler, A. (2017b). The myth of the sharing economy and its implications for regulating innovation. Emory Law Journal, 67(2), 197-241.

Sundararajan, A. (2016). The sharing economy: The end of employment and the rise of crowd-based capitalism. Cambridge, MA: Mit Press.

Sundararajan, A. (2017, February). The collaborative economy: socioeconomic, regulatory and policy issues. Bruxelas, Belgic: Directorate General for Internal Policies, Policy Department A: Economic and Scientific Policy, European Parliament.

Surowiecki, J. (2006). A sabedoria das multidões. Rio de Janeiro, RJ: Record.

Tapscott, D., \& Williams, A. D. (2008). Wikinomics: How mass collaboration changes everything. New York, NY: Penguin Random House.

Terrien, C., Maniak, R., Chen, B., \& Shaheen, S. (2016, September). Good practices for local governments and private companies driving change together in urban mobility: lessons learned from one-way carsharing. California, USA: University of California.

Thierer, A., Koopman, C., Hobson, A., \& Kuiper, C. (2015). How the internet, the sharing economy, and reputational feedback mechanisms solve the lemons problem. U. Miami L. Rev., 70(3), 830-878.

Tomkinson, R. (2017). Shared services in local government: improving service delivery. London, UK: Routledge.

Tribunal de Contas da União. (2015). Política pública de inclusão digital. Brasília, DF: Author.

Turban, E., Outland, J., King, D., Lee, J. K., Liang, T. P., \& Turban, D. C. (2018). Innovative EC Systems: From E-Government to E-Learning, E-Health, Sharing Economy, and P2P Commerce. In E. Turban, J. Outland, D. King, J. K. Lee, T. P. Liang, \& D. C. Turban. (Eds.), Electronic Commerce 2018 (pp. 167201). Cham, Germany: Springer.

Weber, T. A. (2014). Intermediation in a sharing economy: insurance, moral hazard, and rent extraction. Journal of Management Information Systems, 31(3), 35-71. 
RAP | Sharing economy and public governance

Wosskow, D. (2014). Unlocking the sharing economy: an independent review. London, UK: Department for Business, Innovation and Skills.

Zeemering, E. S., \& Delabbio, D. (2013). A county manager's guide to shared services in local government. Washington, DC: IBM Center for the Business of Government.
Zon, N. (2015, December). The sharing economy and why it matters for policy makers. London, UK: Public Sector Digest.

Zrenner, A. (2015). The ethics of regulating the Sharing Economy. Durham, North Carolina: The Kenan Institute for Ethics at Duke University.

\section{Adilson Giovanini}

https://orcid.org/0000-0001-8948-1186

Collaborating professor at the State University of Santa Catarina (UDESC); Ph.D. in Economics from the Graduate Program in Economics at the Federal University of Santa Catarina (UDESC).

E-mail: adilsoneconomia@gmail.com 